\title{
Electrophysiological Responses of Atta sexdens rubropilosa Workers to Essential Oils of Eucalyptus and its Chemical Composition
}

\author{
Luciane G. Batista-Pereira ${ }^{a}$, João B. Fernandes ${ }^{\text {a }}$, M. Fátima G. F. da Silva ${ }^{a}$, \\ Paulo C. Vieira ${ }^{\mathrm{a}}$, Odair C. Bueno ${ }^{\mathrm{b}}$, and Arlene G. Corrêa ${ }^{\mathrm{a}, *}$ \\ a Departamento de Química, Universidade Federal de São Carlos, C.P. 676, 13565-905, \\ São Carlos, SP, Brazil. E-mail: agcorrea@power.ufscar.br \\ b Instituto de Biociências, Centro de Estudos de Insetos Sociais, Universidade Estadual \\ Paulista, 13506-900, Rio Claro, SP, Brazil \\ * Author for correspondence and reprint requests \\ Z. Naturforsch. 61c, 749-755 (2006); received February 1/March 16, 2006
}

\begin{abstract}
The leaf-cutting ant Atta sexdens rubropilosa Forel, 1908 is the most harmful of the Eucalyptus pests, causing severe losses in wood production through defoliation. Various strategies have been tried and effort spent on the development of methods to control this pest, however no practical and environmentally acceptable one currently exists. In this work the chemical composition of the essential oil of seven Eucalyptus species was identified and the selectivity and sensitivity of antennal receptors of $A$. sexdens rubropilosa workers to the volatile compounds were determined using the electroantennographic technique (EAG and GC-EAD). Analysis by GC-EAD showed in E. cloesiana and E. maculata, respectively, seventeen and sixteen terpenes that elicited responses in ant workers' antennae, indicating the potential role of the essential oils as allelochemicals that determine the choice of the foraging material.
\end{abstract}

Key words: Leaf-Cutting Ant, Essential Oil, Electroantennography

\section{Introduction}

The leaf-cutting ants are the major insect problem to agriculture and forestry in Brazil and Atta sexdens rubropilosa Forel, 1908 is one of the principal species of this group. It is the most harmful of the Eucalyptus pests, causing severe losses in wood production through defoliation (Cherret, 1986; Fowler et al., 1989). Various strategies have been tried and substantial effort spent on the development of methods to control this pest, yet no practical and environmentally acceptable one currently exists.

Several plant secondary metabolites exhibit biological activities that have the potential to exert an effect on the physiology and/or behaviour of insects, and it is usually considered that such compounds are involved at some point in plant-insect relationships (Herrera and Pellmyr, 2002). The knowledge of the volatiles of essential oil of the genus Eucalyptus could be used as the basis for a control strategy of the leaf-cutting ants, given that they have a well-developed olfactory system (Hölldobler and Wilson, 1990).

To understand the interactions mediated by semiochemicals, it is necessary to study the factors involved in the olfactory perception of these compounds in order to identify those that could attract $A$. sexdens. To date, the study with electroantennography (EAG) measurements applied to A. sexdens rubropilosa is restrict to two common trail pheromone components, 4-methylpyrrol-2-carboxylate and 2-ethyl-3,6-dimethylpyrazine (Kleineidam et al., 2005).

In this work, we identified the chemical composition of the essential oils of seven Eucalyptus species, which were selected on the basis of foliage characteristics, oil content and resistance by not preference (Anjos et al., 1987; Andrade et al., 1989; Berti-Filho et al., 1991; Boland et al., 1991; Anjos and Santana, 1994; Vendramin et al., 1995). Besides, the selectivity and sensitivity of antennal receptors of $A$. sexdens rubropilosa workers to volatile compounds of these essential oils were determined, using the electroantennographic technique (EAG). Gas chromatography linked on-line to electroantennography detection (GC-EAD) studies were also performed with volatiles sampled from E. cloesiana and E. maculata essential oils. This is the first report of the use of GC-EAD technique for $A$. sexdens rubropilosa. 


\section{Materials and Methods}

\section{Eucalyptus essential oil extraction and analysis}

Fresh leaves of E. grandis Hill ex Maiden, E. citriodora Hook., E. camaldulensis Dehnh., E. saligna Sm., E. urophylla S. F. Blake and E. cloesiana were collected in the forest species arboretum, located in the experimental plantation of the Universidade Estadual Paulista, Botucatu, SP, Brazil. E. maculata leaves were obtained from Universidade Federal de Viçosa, MG, Brazil. The leaves were randomly collected from approx. six-year-old Eucalyptus trees.

The fresh leaves $(400 \mathrm{~g})$ of each species were submitted to steam distillation for $4 \mathrm{~h}$, using a Clevenger apparatus. The essential oils in the distillate were dried over anhydrous $\mathrm{Na}_{2} \mathrm{SO}_{4}$ and kept in the freezer at $0{ }^{\circ} \mathrm{C}$. Essential oils were analyzed using a Shimadzu GC-17A gas chromatograph fitted with a fused silica DB-5 capillary column (30 $\mathrm{m} \times 0.25 \mathrm{~mm}$ ID, $0.25 \mu \mathrm{m}$ film thickness; $\mathrm{J}$ and W Scientific) and with helium as carrier gas at a flow-rate of $1.6 \mathrm{ml} \mathrm{min}^{-1}$. The temperature was held initially at $60^{\circ} \mathrm{C}$ for $2 \mathrm{~min}$ and then increased at a rate of $3{ }^{\circ} \mathrm{C} \mathrm{min}-1$ to $240{ }^{\circ} \mathrm{C}$. The injector was in the split mode at $225^{\circ} \mathrm{C}$. The interface temperature was $250^{\circ} \mathrm{C}$. The chromatograph was coupled to a Shimadzu QP5000 mass selective detector (EIMS) at $70 \mathrm{eV}$. Components were identified by determination of their retention indices relative to those of a homologous series of $n$-alkanes (Dool and Kratz, 1963), by co-injection with authentic samples, and by comparing fragmentation patterns of mass spectra with those stored in the spectrometer database and bibliography (Adams, 1995).

\section{Collection of the insects}

A. sexdens rubropilosa workers were collected from six colonies located at the campus of the Universidade Federal de São Carlos, Central Region of São Paulo State, Brazil. Only larger foragers were collected, i.e., leaf-carrying workers walking along trails.

\section{Electrophysiology}

Antennae of $A$. sexdens rubropilosa workers were used for electroantennographic experiments (EAG) and electroantennographic detection (EAD). Each antenna was pulled from the head with forceps and two segments were cut off at the base (Bjostad, 1998). The antenna was then fixed between two stainless steel electrodes by pushing the base and tip into droplets of an electrically conductive gel (Spectra $360^{\circledR}$ electrode gel, Parker, Orange, New Jersey) applied to the metal electrodes. The antennal responses were amplified and recorded with a data acquisition controller and software EAG (Syntech, Hilversum, The Netherlands).

EAG experiments were performed in order to elucidate the selectivity of the antennal receptors of $A$. sexdens rubropilosa workers. The EAG response was evaluated as follows: The volatile compounds or control were released from Pasteur pipettes containing a piece of filter paper (ca. $0.8 \mathrm{~cm}^{2}$ ) previously impregnated with $10 \mu \mathrm{l}$ of a freshly prepared solution of each test essential oil in hexane, after the solvent had evaporated. The puff containing the test essential oil (from seven Eucalyptus species) was delivered into a continuously humidified and purified air stream (1.2 $1 \mathrm{~min}^{-1}$ ) passing for $0.3 \mathrm{~s}$ through the impregnated filter paper in the pipettes. Control stimulation was made at the beginning and the end of each series of EAG experiments. The essential oils were then applied randomly at intervals of $90 \mathrm{~s}$. EAG amplitudes in response to the essential oils were expressed in relation to the responses to the control (hexane), because of the large differences in overall sensitivity between individual antennae, and to compensate the decline in antennal sensitivity during a measuring session. In this normalization procedure, the responses to the control were defined as $100 \%$. The values obtained between two calibration references (controls) were calculated by linear interpolation between those references values. The Syntech EAG software calculated the normalized values automatically. The essential oils were tested on 20 antennae of $A$. sexdens rubropilosa workers. The mean normalized responses of the different compounds were submitted to ANOVA for statistical analysis and compared by the Tukey test $(P<0.05)$.

The GC-EAD equipment was used to identify individual compounds in the E. cloesiana and $E$. maculata oils capable of eliciting an electroantennographic response. Ten replicates were recorded for $A$. sexdens rubropilosa workers antennae, using essential oils from the two species. The GCEAD instrument consisted of a Shimadzu 17-A gas chromatograph equipped with a flame ionization detector (FID) coupled to an electroantennography system and a DB-5 column $(30 \mathrm{~m} \times$ 
$0.25 \mathrm{~mm}$ ID, $0.25 \mu \mathrm{m}$ film thickness), using the following temperature program: $60^{\circ} \mathrm{C}$ for $1 \mathrm{~min}$, rising at $3{ }^{\circ} \mathrm{C} \mathrm{min}^{-1}$ to $150{ }^{\circ} \mathrm{C}$, held for $10 \mathrm{~min}$, and finally rising at $1{ }^{\circ} \mathrm{C} \mathrm{min}-1$ to $280^{\circ} \mathrm{C}$ and held for $16 \mathrm{~min}$. The column effluent (carrier gas hydrogen) was mixed with a flow of nitrogen make-up gas $\left(12 \mathrm{ml} \mathrm{min}^{-1}\right)$ before it was split to the FID and to a heated transfer capillary leading to the antennal preparation. From the transfer capillary the compounds entered a humidified and purified air stream $\left(1.2 \mathrm{l} \mathrm{min}^{-1}\right)$, which carried them directly over the antennal preparation on the steel electrodes. The FID was kept at $280{ }^{\circ} \mathrm{C}$, whereas the temperature of the transfer capillary was maintained at $290{ }^{\circ} \mathrm{C}$ to avoid condensation.

\section{Results and Discussion}

By the electroantennographic technique a high selectivity of the antennae of $A$. sexdens rubropilosa to the species E. cloesiana, E. camaldulensis, E. urophylla, E. saligna, E. grandis, E. citriodora and E. maculata was evident (Fig. 1). These results indicate the potential role of the essential oils as allelochemicals that determine the choice of the foraging material. When we compared the results obtained with the literature data we can infer that E. cloesiana, followed by the species E. camaldulensis, E. urophylla and E. saligna are the species preferred for the forage in relation to $E$. grandis and E. citriodora. These two last species are more preferred than E. maculata. These results are in agreement with the results of behavioral assays obtained by Andrade et al (1989) and Vendramin et al. (1995), where the species E. camaldulensis, E. urophylla and E. saligna were preferred in com- parison to E. grandis and E. citriodora. These two species were considered resistant by not preference. Anjos et al. (1986) verified that among the 20 species of eucalyptus more planted in Brazil, E. maculata was considered highly resistant to $A$. sexdens rubropilosa. Anjos and Santana (1994) demonstrated the negative effect in the behavior and in the survival of $A$. sexdens caused by $E$. maculata leaves; this effect was not evidenced for the species E. grandis and E. citriodora.

Composition of each essential oil of Eucalyptus is given in Tables I and II. Component relative concentrations were calculated from GC peak areas and arranged in order of GC elution.

E. cloesiana and E. maculata essential oils were chosen for the coupled gas chromatography-electroantennography detection (GC-EAD) experiment because they caused, respectively, the greater and the smaller depolarization in the $A$. sexdens antennae by the EAG technique.

It was verified that E. cloesiana essential oil presented 32 compounds 15 of which were identified, corresponding to $93.84 \%$ of the total oil mass (Tables I and II). The major component in the oil was $\alpha$-pinene corresponding to $76.08 \%$ of the total mass. It was observed that the oil is constituted basically by terpenes.

Thirty-seven compounds were found in the $E$. maculata essential oil, 18 of which were identified, equivalent to $74.2 \%$ of the total mass (Tables I and II). Again, the major component was $\alpha$-pinene $(39.4 \%)$ followed by $\beta$-caryophyllene $(10.34 \%), \beta$ pinene $(6.87 \%)$ and limonene $(2.68 \%)$.

This research is pioneering in the employment of the GC-EAD technique to verify the olfactory sensitivity of $A$. sexdens rubropilosa workers. With
Fig. 1. Mean EAG ( \pm SD) elicited from Atta sexdens rubropilosa worker antennae at the concentration of $100 \mathrm{mg} \mathrm{ml}^{-1}$ of Eucalyptus essential oils. Mean values marked with the same letter are not significantly different at $P<0.05$ on the basis of the Tukey test $(N=20$ antennae).

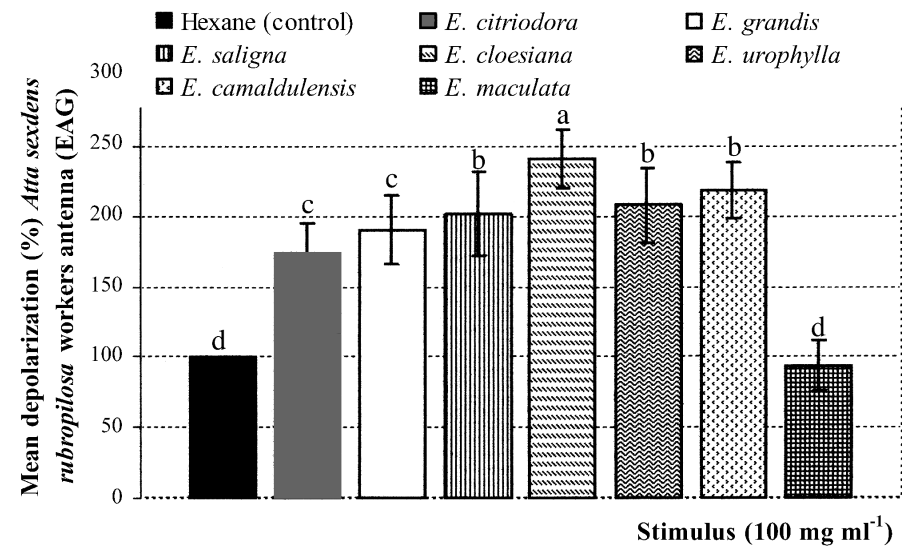


Table I. Essential oil composition (\%) from E. cloesiana (ECL), E. saligna (ES), E. citriodora (EC), E. camaldulensis (ECA), E. grandis (EG), E. urophylla (EU) and E. maculata (EM) compared to Adams (1995).

\begin{tabular}{|c|c|c|c|c|c|c|c|c|}
\hline $\begin{array}{l}\text { Compound } \\
\text { identified }\end{array}$ & $\begin{array}{l}\text { Adams } \\
\text { KI }\end{array}$ & $\begin{array}{c}\text { ECL }(\%) \\
\text { KI obs }\end{array}$ & $\begin{array}{l}\text { ES }(\%) \\
\text { KI obs }\end{array}$ & $\begin{array}{c}\text { EC }(\%) \\
\text { KI obs }\end{array}$ & $\begin{array}{c}\text { ECA }(\%) \\
\text { KI obs }\end{array}$ & $\begin{array}{l}\text { EG }(\%) \\
\text { KI obs }\end{array}$ & $\begin{array}{l}\text { EU }(\%) \\
\text { KI obs }\end{array}$ & $\begin{array}{c}\text { EM (\%) } \\
\text { KI obs }\end{array}$ \\
\hline Tricyclene & 926 & 0.42 & & & 0.09 & & 0.16 & \\
\hline$\alpha$-Pinene & 932 & 76.08 & 25.91 & 0.28 & 6.12 & 40.55 & 8.03 & 39.4 \\
\hline$\alpha$-Fenchene & 946 & 0.17 & 0.09 & & & 0.3 & & \\
\hline$\beta$-Pinene & 975 & 2.21 & & 0.58 & 2.37 & 0.23 & 4.59 & 6.87 \\
\hline Myrcene & 991 & & & & 0.61 & & 0.76 & \\
\hline$\alpha$-Phellandrene & 1004 & & 0.53 & & 0.19 & 1.83 & 4.02 & \\
\hline$n$-Pentyl isobutyrate & 1012 & & 0.42 & & & 0.55 & & \\
\hline Isosylvestrene & 1014 & & & & 0.15 & & 0.16 & \\
\hline$o$-Cymene & 1021 & 0.16 & 24.38 & & 2.13 & 13.13 & 2.5 & \\
\hline Limonene & 1024 & 2.66 & 1.57 & & 14.22 & 2.66 & 7.13 & 2.68 \\
\hline 1,8-Cineole & 1028 & & 6.86 & & 52.82 & 0.45 & 53.11 & \\
\hline$(Z)$ - $\beta$-Ocimene & 1033 & & & & & 0.2 & 2.92 & 0.93 \\
\hline$(E)-\beta$-Ocimene & 1043 & & & & & 0.34 & 0.68 & \\
\hline$\gamma$-Terpinene & 1054 & & 24.63 & & 6.79 & 16.25 & 0.69 & \\
\hline $2,4(8)$ - $p$-Menthadiene & 1080 & 0.43 & 0.7 & & 1.22 & 0.78 & 0.65 & \\
\hline Linalool & 1093 & & 0.28 & & 0.14 & 0.84 & 0.19 & \\
\hline exo-Fenchol & 1106 & & 0.13 & & & 0.42 & & \\
\hline$\alpha$-Canpholenol & 1119 & & 1.27 & & & 2.29 & & \\
\hline trans-Pinocarveol & 1132 & & 0.27 & & & 0.27 & & \\
\hline neo-iso-3-Thujanol & 1139 & & & 11.84 & & & & \\
\hline Citronellal & 1150 & & & 75.99 & 1.09 & & & \\
\hline trans-Pinocamphone & 1156 & & 0.11 & & & 0.17 & & \\
\hline Isoborneol & 1161 & & 0.21 & & & 0.76 & & \\
\hline Terpin-4-ol & 1174 & 0.38 & 2.29 & & 2.64 & 1.27 & 0.89 & \\
\hline p-Cimen-8-ol & 1183 & & 0.09 & & & 2.9 & & \\
\hline$\alpha$-Terpineol & 1188 & 3.81 & 2.19 & & 2.83 & 2.90 & 2.97 & 0.82 \\
\hline trans-Carveol & 1218 & & 0.46 & & & & & \\
\hline Citronellol & 1332 & & & 5.42 & & & & \\
\hline$p$-Cimen-7-ol & 1287 & & 0.15 & & & & & \\
\hline Carvocrol & 1302 & & 0.12 & & & & & \\
\hline$\alpha$-Terpenyl acetate & 1350 & & 0.37 & & & & 4.38 & \\
\hline$\alpha$-Gurjunene & 1408 & & 0.24 & & 0.24 & 0.29 & 0.33 & 0.2 \\
\hline$\beta$-Caryophyllene & 1417 & 2.33 & 0.25 & 0.52 & & 1.19 & & 10.34 \\
\hline Aromadendrene & 1437 & 0.85 & & & 0.94 & 0.6 & & 2.81 \\
\hline Seychellene & 1460 & & 0.17 & & 0.38 & 0.88 & & 0.73 \\
\hline Bicyclogermacrene & 1497 & & 0.98 & & 0.55 & 2.2 & 0.2 & \\
\hline$(E, E)$ - $\alpha$-Farnesene & 1511 & & & & & 0.19 & & \\
\hline Geranyl isobutyrate & 1517 & & 0.28 & & & & & \\
\hline$\alpha$-Cadinene & 1524 & & & & & & 0.23 & 0.40 \\
\hline Elemol & 1550 & & & & & & & 0.53 \\
\hline$\alpha$-Cadinene & 1559 & & & & & & & 0.30 \\
\hline Spathulenol & 1576 & 1.9 & 0.32 & & & 0.95 & & 0.55 \\
\hline Nerolidol & 1583 & 0.98 & 0.37 & & 0.88 & 0.57 & 0.29 & 3.78 \\
\hline$\gamma$-Eudesmol & 1631 & & & & 0.1 & & & 0.38 \\
\hline$\beta$-Eudesmol & 1649 & 0.48 & & & 0.36 & & & 0.66 \\
\hline$\alpha$-Eudesmol & 1652 & 0.67 & & & 0.28 & & & 1.02 \\
\hline Guaiol epimer & 1658 & & & & & & & 0.45 \\
\hline
\end{tabular}

the GC-EAD technique it was possible to detect 17 bioactive compounds present in E. cloesiana essential oil that stimulated the antennae of $A$. sexdens workers (Fig. 2). Of these bioactive compounds 12 were identified as: $\alpha$-pinene (peak 1 ), $\beta$-pinene (2), limonene (3), 2,4(8)- $p$-menthadiene (4), terpin-4-ol (7), $\alpha$-terpineol (8), $\beta$-caryophyl- lene (9), aromadendrene (10), spathulenol (13), nerolidol (14), $\beta$-eudesmol (16), and $\alpha$-eudesmol (17).

In the E. maculata essential oil (Fig. 3), by GCEAD, it was possible to detect 16 bioactive compounds. Efforts were made to identify all 16 of the stimulatory compounds among the volatile frac- 
L. G. Batista-Pereira et al. · Electrophysiological Responses of Atta sexdens rubropilosa

Table II. Not identified compounds observed in the essential oil from E. cloesiana (ECL), E. saligna (ES), E. citriodora (EC), E. camaldulensis (ECA), E. grandis (EG), E. urophylla (EU) and E. maculata (EM).

\begin{tabular}{|c|c|c|c|c|c|c|c|}
\hline $\begin{array}{l}\text { Compound not identified } \\
\text { KI observed }\end{array}$ & ECL (\%) & ES (\%) & EC (\%) & ECA $(\%)$ & EG (\%) & EU (\%) & EM (\%) \\
\hline 906 & 0.23 & & & 0.08 & & & 6.23 \\
\hline 913 & 0.27 & 0.86 & & & 0.31 & & \\
\hline 921 & 0.19 & & & 0.13 & & & 4.1 \\
\hline 931 & & & & & & & \\
\hline 963 & & & & & & & 0.4 \\
\hline 965 & & & & 0.06 & & & \\
\hline 1015 & & 0.35 & & & 0.27 & & \\
\hline 1033 & & & & 0.16 & & & \\
\hline 1066 & & 0.36 & & & 0.38 & & \\
\hline 1083 & & 0.1 & & & 0.18 & & \\
\hline 1092 & & & 0.47 & & & & \\
\hline 1099 & & & & 0.1 & & & \\
\hline 1106 & 0.2 & & & & & 0.15 & \\
\hline 1140 & & & & 0.21 & & & \\
\hline 1143 & & & 0.51 & & & & \\
\hline 1164 & 0.22 & & 0.88 & & & & \\
\hline 1196 & & 1.32 & & & & & \\
\hline 1255 & & & & 0.22 & & & \\
\hline 1267 & & 0.16 & & & & & \\
\hline 1332 & & & 0.7 & & & & \\
\hline 1336 & & & & & & & 0.62 \\
\hline 1342 & & & & & & 0.17 & \\
\hline 1358 & 0.56 & & & & & & \\
\hline 1366 & 0.8 & & & & & & \\
\hline 1374 & & & & & & & 0.5 \\
\hline 1386 & & & & & & & 0.25 \\
\hline 1395 & & 0.17 & & & & & \\
\hline 1413 & & 0.27 & & & & & \\
\hline 1442 & & & & & 0.3 & & 0.44 \\
\hline 1453 & 0.32 & & & & 0.17 & & 1.12 \\
\hline 1476 & & & 0.56 & & & & \\
\hline 1479 & & & 0.84 & & & & \\
\hline 1482 & & & & 0.86 & & & \\
\hline 1488 & & & & & & & 0.19 \\
\hline 1491 & & & & 0.21 & & & \\
\hline 1495 & & & & & & & 1.37 \\
\hline 1498 & 0.71 & & 1.13 & & & & 1.51 \\
\hline 1504 & 0.16 & & & & & & \\
\hline 1522 & 1.16 & & & & & & \\
\hline 1545 & 0.39 & & & & & & \\
\hline 1566 & & 0.11 & & & & & 0.31 \\
\hline 1590 & 0.21 & 0.34 & 0.27 & 0.24 & 0.5 & & 0.96 \\
\hline 1592 & & 0.24 & & & 0.3 & & 0.99 \\
\hline 1597 & & & & & & & 3.99 \\
\hline 1600 & & 0.14 & & & 0.23 & & 0.81 \\
\hline 1620 & & & & & 1.82 & & \\
\hline 1622 & & 0.14 & & 0.13 & & & 0.82 \\
\hline 1627 & 0.34 & & & & & & 0.67 \\
\hline 1649 & 0.51 & & & & & & \\
\hline 1652 & 0.48 & & & & & & \\
\hline 1668 & 0.67 & & & & & & 0.58 \\
\hline 1972 & & & & & & 0.42 & \\
\hline
\end{tabular}

tions eluted from the oil of eucalyptus; however, only 11 could be identified: $\alpha$-pinene (peak 1 ), $\beta$ pinene (2), limonene (3), $\alpha$-terpineol (5), $\beta$-caryo- phyllene (8), aromadendrene (9), elemol (11), spathulenol (12), nerolidol (13), $\beta$-eudesmol (15), and $\alpha$-eudesmol (16). 

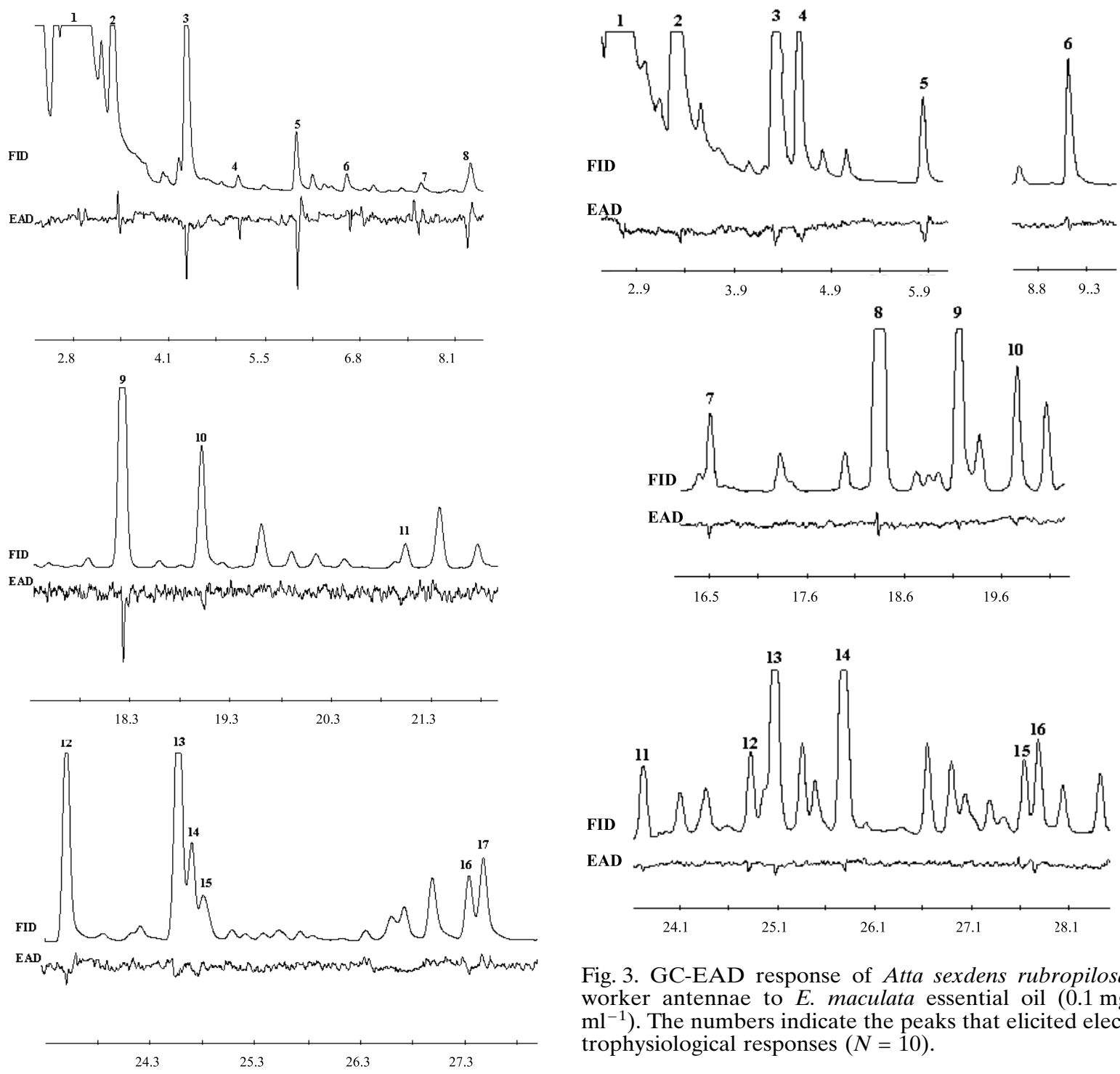

Fig. 3. GC-EAD response of Atta sexdens rubropilosa worker antennae to $E$. maculata essential oil $(0.1 \mathrm{mg}$ $\left.\mathrm{ml}^{-1}\right)$. The numbers indicate the peaks that elicited electrophysiological responses $(N=10)$.

Fig. 2. GC-EAD response of Atta sexdens rubropilosa worker antennae to E. cloesiana essential oil $(0.1 \mathrm{mg}$ $\left.\mathrm{ml}^{-1}\right)$. The numbers indicate the peaks that elicited electrophysiological responses $(N=10)$.

Ten bioactive compounds were almost chemically identical in E. cloesiana and E. maculata species. The compounds 2,4(8)-p-menthadiene (4) and terpin-4-ol (7) were present only in E. cloesiana essential oil while elemol (11) only in $E$. maculata essential oil. Of these results it can be inferred that the difference in the depolarizations, obtained for EAG and EAD, could be related to

these compounds and mainly to the ratio of each compound, since in each oil they presented a different percentage. Besides, the differences in depolarizations could also be attributed to bioactive compounds not identified in each essential oil. According to Barnola et al. (1997) and Barnola and Cedeño (2000), the concentration of some terpenes, mainly $\beta$-pinene and $\beta$-caryophyllene, would be responsible for the difference in the attack of the $A$. laevigata leaf-cutting ant observed in the forestry species Pinus caribaea. In accordance with the same authors, $\beta$-caryophyllene, with occurrence in high percentage, would have a repellent 
effect to A. laevigata. Of this form, the difference in the antennal response noticed for $A$. sexdens by EAG in E. maculata can be related with the presence of blend in high percentages of $\beta$-pinene $(6.87 \%)$ with $\beta$-caryophyllene $(10.34 \%)$; hence in E. cloesiana $(2.21 \% \beta$-pinene and $2.33 \% \beta$-caryophyllene) and in other Eucalyptus species these compounds were present in low concentrations. Moreover, Marsaro et al. (2004) demonstrated, by behavioral assays, that hexane extracts of E. maculata interfered in recognition mechanism among workers. The main active compounds identified from this plant were elemol and $\beta$-eudesmol. These compounds may be responsible for the resistance of this species to ant attack.

In this study, it was verified that some terpenes, found in essential oils of E. cloesiana and E. maculata, are bioactive in the antennae of $A$. sexdens rubropilosa workers. These results indicate that

Adams R. P. (1995), Identification of Essential Oil Components by Gas Chromatography/Mass Spectroscopy. Allured Publishing, New York, p. 469.

Andrade M. L., Forti L. C., Padovani C. R., and Pacheco P. (1989), Preferência de Atta sexdens rubropilosa Forel, 1908 (Hymenoptera: Formicidae) por diferentes espécies de Eucalyptus. In: Encontro de Mirmecologia, Vol. 9. Viçosa, Brazil, p. 19.

Anjos N. and Santana D. L. Q. (1994), Alterações deletérias no comportamento de Atta laevigata (F. Smith) e Atta sexdens rubropilosa Forel (Hymenoptera: Formicidae), causadas por folhas de Eucalyptus spp. An. Soc. Entomol. Brasil 23, 25-30.

Anjos N., Santos G. P., and Zanuncio J. C. (1986), Resistência de Eucalyptus spp. a saúva-limão, Atta sexdens rubropilosa Forel, 1908 (Hymenoptera: Formicidae). In: Congresso Brasileiro de Entomologia, Vol. 10. Rio de Janeiro, Brazil, p. 404.

Anjos N., Santos G. P., and Zanúncio J. C. (1987), A lagarta parda, Thyrinteina arnobia (Stoll, 1782) (Lepidoptera: Geometridae) desfolhadora de eucaliptos. Bol. Tec. Epamig 25, 1-56.

Barnola L. F. and Cedeño A. (2000), Inter-population differences in the essential oils of Pinus caribaea needles. Biochem. Syst. Ecol. 28, 923-931.

Barnola L. F., Cedeño A., and Hasegawa M. (1997), Intraindividual variations of volatile terpene contents in Pinus caribaea needles and its possible relationship to Atta laevigata herbivory. Biochem. Syst. Ecol. 25, 707-716.

Berti-Filho E., Stape J. L., and Cerignoni J. A. (1991), Surto de Thyrinteina arnobia (Stoll, 1782) (Lepidoptera: Geometridae) em Eucalyptus citriodora Hook (Myrtaceae) no estado de São Paulo. Rev. Agric. 66, 47-51. the GC-EAD analysis is a useful technique for the selection of compounds present in plant extracts that have importance in the behavior of insects. The results obtained from the electroantennographic technique also suggest that $A$. sexdens rubropilosa workers use some volatile compounds as signals to find the host. But the relevance of these allelochemicals remains to be determined, i.e, if the bioactive compounds are satisfactorily attractive and specific in the field.

\section{Acknowledgements}

The authors are grateful to MCT-PRONEX/ FINEP, CNPq, FAPESP and IFS/ OPCW for the financial support. L. G. B.-P. thanks FAPESP for the award of a fellowship. We are also grateful to Dr. C. F. Wilcken, UNESP, Botucatu, Brazil, for providing us the leaves of the seven Eucalyptus species used for the extraction of essential oils.

Bjostad L. B. (1998), Electrophysiological methods. In: Methods in Chemical Ecology: Chemical Methods, Vol. 1 (Haynes K. F. and Millar J. G., eds.). Chapman and Hall, London, p. 339-369.

Boland D. J., Brophy J. J., and House A. P. N. (1991), Eucalyptus Leaf Oils: Use, Chemistry, Distillation and Marketing. Inkata Press, Melbourne, p. 252.

Cherret J. M. (1986), The biology pests status and control of leaf-cutting ants. Agric. Zool. Rev. 1, 1-37.

Dool H. V. D. and Kratz P. D. (1963), A generalization of the retention index system including linear temperature programmed gas-liquid partition chromatography. J. Chromatogr. 11, 463-471.

Fowler H. G., Pagani M. I., da Silva O. A., Forti L. C., da Silva V. P., and Vasconcelos H. L. (1989), A pest is a pest. The dilemma of Neotropical leaf-cutting ants: keystone taxa of natural ecosystems. Environ. Manag. 13, $71-675$.

Herrera M. C. and Pellmyr O. (2002), Plant-Animal Interactions: an Evolutionary Approach. Blackwell Publishing, Oxford.

Hölldobler B. and Wilson E. O. (1990), The Ants. The Belknap Press of Harvard University Press, Cambridge, p. 732.

Kleineidam C. J. Obermayer M., Halbich W., and Rossler W. (2005), A macroglomerulus in the antennal lobe of leaf-cutting ant workers and its possible functional significance. Chem. Senses 30, 383-392.

Marsaro A. L., Souza R. C., Della Lucia T. M., Fernandes J. B., Silva M. F. G. F., and Vieira P. C. (2004), Behavioral changes in workers of the leaf-cutting ant Atta sexdens rubropilosa induced by chemical components of Eucalyptus maculata leaves. J. Chem. Ecol. 30, $1771-1780$.

Vendramin J. D., Silveira Neto S., and Cerignoni J. A. (1995), Não preferência de Atta sexdens Forel, 1908 por espécies de Eucalyptus. Ecossistema 20, 87-92. 